\title{
Zaštita privatnosti djece i maloljetnika na društvenoj mreži Facebook: navike i iskustva roditelja
}

Prethodno priopćenje _ DOI 10.22522/cmr20190141__ primljeno 19. siječnja 2018. UDK: 366.5-053.5:004.738-028.46-055.52

\section{Tanja Grmuša}

Poslovno veleučilište Zagreb, Zagreb, Hrvatska. E-adresa: tanja.grmusa@pvzg.hr

\section{Ana Marguerite Tomulić}

Hrvatska gospodarska komora, Zagreb, Hrvatska. E-adresa: atomulic@hgk.hr

\section{Vedrana Anđelić}

Hrvatski zavod za hitnu medicinu, Zagreb, Hrvatska. E-adresa: andjelic.vedrana@gmail.com

\section{Sažetak}

Komunikacija na društvenoj mreži Facebook postala je svojevrsni digitalni dnevnik u kojemu se intima pojedinca, njegovih poznanika i članova obitelji izlaže (pr)ocjenjivanju javnosti (Jelavić, 2009), a broj Facebook prijatelja služi kao alat za mjerenje društvenog kapitala (Krolo, 2015). U porastu su trendovi objave fotografija djece i maloljetnika koje njihovi roditelji (ne)svjesno dijele, često bez znanja i pristanka djece, kreirajući pritom njihov digitalni identitet i ne mareći o zaštiti privatnosti te posljedicama (Gabelica Šupljika, 2009). lako se o dječjim pravima mnogo govori, a njihovo je provođenje regulirano brojnim međunarodnim propisima (Livingstone, O’Neill, 2014), zaštita privatnosti djece u digitalnom svijetu čini se još uvijek nedovoljnom. Europski je parlament sredinom 2016. usvojio Opću uredbu o zaštiti osobnih podataka (General Data Protection Regulation - GDPR), čija je primjena obvezujuća za sve zemlje članice EU-a od 2018. godine. Prema Uredbi djeca u dobi do 13, odnosno do 16 godina, ovisno o nacionalnoj regulativi zemlje članice, pristup društvenim mrežama neće moći ostvariti bez pristanka roditelja. Na ovaj se način nastoji poboljšati zaštita djece i maloljetnika u digitalnoj sferi, jačati medijska pismenost, ali i osnažiti uloga roditelja u medijskom odgoju djece. Rad će prikazati rezultate istraživanja provedenog metodom ankete među roditeljima korisnicima Facebooka s područja grada Zagreba. Cilj istraživanja bio je ispitati korisničke preferencije (navike) upotrebe društvene mreže Facebook kod roditeljske populacije, ispitati svjesnost roditelja o rizicima komunikacije na društvenoj mreži Facebook, utvrditi znanje roditelja o mehanizmima zaštite privatnosti na društvenoj mreži Facebook te istražiti upoznatost roditelja s GDPR uredbom, kao i njihovo mišljenje o njoj.

Ključne riječi: djeca, novi mediji, Facebook, digitalni identitet, roditelji, zaštita privatnosti, GDPR, medijska pismenost

*Sadržaj rada temelji se na osobnim stavovima autorice i ne odražava stav Hrvatske gospodarske komore. 


\section{Uvod}

Razvoj novih informacijsko-komunikacijskih tehnologija u posljednja dva desetljeća značajno je utjecao na društvene odnose koji su tehnološki posredovani (usp. Nikodem, 2003, str. 221), pri čemu se sve više propituje uloga čovjeka i njegova identiteta. Društvene mreže postale su „mjesta susreta, kreiranja i komunikacije“ (Mučalo, Šop, 2008, str. 53), a komuniciranje putem digitalnih kanala predstavlja težnju za obnovom zajedništva u javnoj sferi, dodaje Nikodem (2003), naglašavajući ulogu vrijednosti kao faktora socijalizacije i identifikacije s drugima.

Medijska socijalizacija se, kako ističe Valković (usp. 2006, str. 102), odvija prema nepripremljenim obrascima, te služi promociji vrijednosti i normi. Socijalizacija $\mathrm{u}$ kontekstu društvenih mreža treba se promatrati u kontekstu individualizacije i personalizacije medijske konzumacije, pri čemu su važna znanja i vještine korisnika u iščitavanju (skrivenih) poruka, ali i odgovornoj upotrebi društvenih mreža te dijeljenju osobnih podataka. Zato nam je potreban medijski odgoj koji „uključuje promišljanje kako bi osoba mogla samostalno i odgovorno djelovati“"(Valković, 2016, str. 102), a važnu ulogu u tom procesu imaju roditelji i obitelj koja može utjecati na razumijevanje života (realnoga i virtualnoga). No, za to je potreban i određeni pravni okvir, čemu je doprinos dao Europski parlament koji je usvojio Opću uredbu o zaštiti osobnih podataka čija primjena kreće u prvoj polovini 2018. godine. Iako su roditelji u posljednjih nekoliko godina u središtu brojnih istraživanja koja se bave djecom i medijima (usp. Sindik, 2008; Ciboci, Kanižaj, Labaš, 2014; Ciboci, 2015), cilj je ovoga pionirskoga rada istražiti obrasce ponašanja roditelja na društvenoj mreži Facebook, njihovo znanje o zaštiti vlastitih dijeljenih sadržaja i osobnih podataka, kao i tuđih sadržaja i osobnih podataka te upoznatost $\mathrm{s}$ GDPR-om. 


\section{Društvene mreže kao socijalni kapital}

Korištenje društvene mreže Facebook $u$ posljednjih se nekoliko godina proučava $u$ kontekstu kvalitete i dinamike komuniciranja ${ }^{1}$, ističe Krolo (usp. 2015, str. 146). Naime, veliki broj virtualnih prijatelja ${ }^{2}$ na korisničkim profilima ne mora odražavati stvarno stanje interpersonalnih kontakata koje pojedinac svakodnevno ostvaruje, već u njihovoj analizi treba uzeti $\mathrm{u}$ obzir i relevantnost brojki te razloge takvim pokazateljima. Autor pitanje kontakata i komunikacije na Facebooku stavlja u kontekst društvenog kapitala $\mathrm{s}$ ciljem proučavanja veza online zajednice korisnika i korisnica (usp. 2015, str. 147).

„...Putnam društveni kapital vidi kao 'obilježja društvenih organizacija, poput povjerenja, normi i mreža koje mogu poboljšati $u$ učinkovitost društva olakšavanjem posredovanja $u$ koordiniranom djelovanju' (Putnam, 2001 [2000], str. 169)“ (Krolo, 2015, str. 147). Putnam ističe dvije prizme društvenoga kapitala - strukturnu i kulturnu. I dok prva promatra stvaranje mreža među članovima zajednice, druga se „operacionalizira kao povjerenje među ljudima koje se generira osnovu normi ili specifičnog seta političkih, povijesnih i kulturnih karakteristika određenog društvenog konteksta ili zajednice“ (Krolo, 2015, str. 148). U središtu Putnamova koncepta nalazi se interakcija kao jedan od preduvjeta uspješne interpersonalne komunikacije $\mathrm{u}$ kontekstu stvaranja mreža interpersonalnih kontakata (Reardon, 1998; De Vito, 2016). Istodobno, Putnam medije percipira faktorom koji doprinosi smanjenju društvenih interakcija te raspadom društvenih mreža/odnosa među ljudima, što Krolo (usp. 2015, str. 149) tumači usmjerenošću Putnama na specifičnosti obilježja tradicionalnih medija koji nisu mogli osigurati interaktivnost i povezanost $u$ odnosu na nove medije i internetske društvene mreže koji to vrlo uspješno čine.

Pojam društvenoga kapitala proučavao se do sada u Hrvatskoj u različitim aspektima: a) politološkome $\mathrm{u}$ kontekstu utjecaja internetskih društvenih mreža na političku participaciju mladih kao dio društvenog kapitala (Pavić, Šundalić, 2015), b) sociološkome i utjecaju društvenih mreža na građanski aktivizam (Krolo, Puzek, 2014), proučavanja odrednica društvenog kapitala s obzirom na stupanj urbaniziranosti naselja stanovanja $\mathrm{u}$ kontekstu povjerenja $\mathrm{u}$ političke i društvene institucije te građanskog aktivizma $\mathrm{u}$

1 Broj korisnika Facebooka u Hrvatskoj doseže 1,9 milijuna prema istraživanju agencije Arbona, pri čemu su najaktivniji korisnici u dobi od 13 do 34 godine, kao i oni u urbanim sredinama (usp. Vitas, 2016).

2 Istraživanje o navikama korištenja Facebooka u Hrvatskoj Tvornice istraživanja na uzorku od 346 ispitanika pokazalo je kako je uporaba ove društvene mreže postala rutina, budući da su ispitanici potvrdili kako su cijelo vrijeme ulogirani na svoje račune te imaju stotine prijatelja, a čak $65 \%$ njih i ne poznaju (usp. Kostanić, 2017). 
društvu (Majetić, Rajter, Dević, 2017), društveni angažman građana (Tomić-Koludrović, 2007) te c) kulturološkome u kontekstu utjecaja društvenog kapitala na razvojne procese tranzicijskih zemalja Srednje i Istočne Europe (Dragojević, 1995).

Uporaba Facebooka služi za održavanje postojećih društvenih veza, a kada je riječ o stvaranju novih kontakata, tada se oni uglavnom ostvaruju na temelju sličnosti (sociokulturnih i svjetonazorskih) s drugima, navodi Krolo (usp. 2015, str. 150). No, pojedina istraživanja (usp. Wellman i sur., 2001, str. 436-455; Corrigalt-Brown, Wilkes, 2014 prema Pavić, Šundalić, 2015, str. 129-130) potvrđuju kako internet promatran općenito kao medij može utjecati i na smanjenje socijalnog kapitala u kontekstu nedostatka povratne informacije, zatim smanjenja vremena za interakciju u realnom svijetu, što u konačnici može rezultirati i otuđenjem pojedinca od stvarnosti. Navedeno se često događa kod djece i maloljetnika koja nerijetko u online komunikaciji zbog neznanja prakticiraju rizična ponašanja, ne razmišljajući pritom o posljedicama takvog djelovanja, stoga im je, uz edukaciju, potrebno osigurati i odgovarajući pravni okvir koji bi ih dodatno zaštitio.

\section{Zakonodavni okvir zaštite djece i maloljetnilka u. novim medijima}

\subsection{Privatnost djece $u$ novim medijima}

Pravo na privatnost jedno je od temeljnih ljudskih prava i tekovina zapadnog kulturnog kruga, a Boban ga definira (2012, str. 582) na sljedeći način: „kao čovjekovo pravo međunarodnopravne prirode, kao temeljno ustavom zagarantirano pravo te kao osobno pravo zaštićeno instrumentima građanskog prava“. Pojam privatnosti složen je i višedimenzionalan te obuhvaća prostornu, informacijsku i komunikacijsku privatnost (usp. Boban, 2012, str. 584). O ovoj drugoj dimenziji, koja je u središtu i ovoga rada, u posljednje se vrijeme sve više govori i istražuje (usp. Klarić, 2016; Dokman, Kuzelj, Malnar, 2018), zbog uspona društvenih mreža i ostalih internetskih servisa koji prikupljaju, obrađuju i upravljaju podacima korisnika. Istodobno, osobni podaci postali su poželjna valuta poslovanja brojnih dionika (online servisa, marketinških agencija, političkih stranaka i ostalih interesnih grupacija), što pojačava i rizike njihove zlouporabe. 
Zgrabljić Rotar (2009) podsjeća kako je redefiniranje pojma privatnosti započeto razvojem interneta, čime je došlo i do porasta rizika za djecu i maloljetnike ${ }^{3} u$ vidu objava osobnih podataka, fotografija, čime se otkriva identitet maloljetnika, te ih se izlaže prijevarama, zlostavljanjima, ponižavanjima, uznemiravanju te brojnim neprimjerenim sadržajima (usp. Kušić, 2010, str. 107). Dodatan problem zaštiti privatnosti predstavlja i generacijski jaz te činjenica da su djeca vještija i medijski pismenija od roditelja, a interakcija u novim medijima zahtijeva i odgovornost komunikatora (usp. Hamelink, 1998 prema Zgrabljić Rotar, 2009, str. 38).

Iako je zakonodavni okvir zaštite privatnosti poprilično širok ${ }^{4}$, Jelavić upozorava kako svako neprimjereno izlaganje djeteta (novim) medijima može doprinijeti njegovoj sekundarnoj viktimizaciji, ističući odgovornost roditelja koji nerijetko sami iniciraju objave o vlastitoj djeci (usp. Jelavić, 2009, str. 15), bez njihove suglasnosti. Otkrivanje identiteta djeteta može se odvijati na izravan i na posredan način; od objave fotografije pa do otkrivanja djetetovih inicijala, mjesta stanovanja, detalja iz obiteljskoga života, upozorava Gabelica Šupljika (usp. 2009, str. 21), dodajući kako je riječ o nepromišljenom i neodgovornom ponašanju, ali i o nedovoljnom znanju o posljedicama objave takvog sadržaja, budući da objavom materijale čine javno dostupnim, gubeći tako kontrolu nad njihovom daljnjom distribucijom i prezentacijom (usp. 2009, str. 30), što za dijete kao aktera objave dugoročno može imati dalekosežne posljedice. Problem je prepoznat i na razini Europske unije koja je u sklopu nove Opće uredbe o zaštiti osobnih podataka (GDPR) odlučila pružiti snažniji odgovor $^{5}$ zaštite ranjivih skupina poput djece i maloljetnika.

\footnotetext{
3 Istraživanje Hrabrog telefona i Poliklinike za zaštitu djece i mladih grada Zagreba provedeno 2013. godine na nacionalno reprezentativnom uzorku od 1489 djece i mladih u dobi od 11 do 18 godina pokazalo je kako čak $85 \%$ djece i mladih na mreži Facebook dijeli svoje puno ime i prezime, 38 \% vlastitu e-mail adresu te 31 \% ime škole koje pohađaju, a najčešće informacije koje dijele su privatne fotografije ( $43 \%)$. Također, istraživanje je pokazalo kako se svako peto dijete (21\%) susrelo s uvredljivim komentarima na Facebooku, a čak 16 \% djece barem je jednom putem Facebooka primilo neželjene poruke seksualnih sadržaja, a svakom šestom djetetu (15 \%) su putem Facebooka upućene prijetnje (usp. Poliklinika za zaštitu djece i mladih grada Zagreba, 2014).

4 Podsjetimo, Ustav Republike Hrvatske djetetu jamči štovanje i pravnu zaštitu njegovog osobnog života i obiteljskog života, dostojanstva, ugleda i časti te sigurnost i tajnost osobnih podataka. Tajnost osobnih podataka štiti i Zakon o zaštiti osobnih podataka, a nadzor nad obradom osobnih podataka provodi Agencija za zaštitu osobnih podataka (usp. Mudražija, 2017). 5 Podsjetimo, EU je 1989. godine donijela direktivu „Televizija bez granica“, čiji je primarni cilj bio uspostaviti zajedničko tržište, definirala između ostaloga zaštitu djece i maloljetnika od izloženosti sadržajima koji prikazuju nasilje ili pornografiju. Spomenuta direktiva dopunjena je 1997. godine amandmanima koji su nastojali osigurati jednaki pristup medijima svima neovisno o geografskom području, uskladiti pravila oglašavanja te osigurati najmanje $50 \%$ sadržaja europske produkcije. No, navedeni dokumenti nisu pratili strelovit razvoj informacijsko-komunikacijskih tehnologija i novih medija, za koje je trebalo ponuditi odgovarajući okvir. Uslijedila je Direktiva o audiovizualnim medijskim uslugama, usvojena 2007. godine, a primjenjivana od 2010. godine koja je obuhvatila internetsku televiziju (i usluge na zahtjev), ublažila odredbe o televizijskom oglašavanju te otvorila pitanja zaštite djece i maloljetnika.
} 


\subsection{GDPR uredba - prilagodba privatnosti djeteta digitalnoj sferi?}

Sve brži tehnološki razvoj u zadnja dva desetljeća postavio je nove izazove za zaštitu osobnih podataka u digitalnoj sferi. Naime, digitalizacija, u obliku pojave društvenih mreža te mnogobrojnih mobilnih aplikacija, ubrzala je protok informacija koje ujedno sadrže i osobne podatke. Potrošači, ali i regulatori, postaju sve skeptičniji u pogledu obećanja koje tvrtke daju o korištenju osobnih podataka kupaca. Pritom poseban razlog zabrinutosti u očima regulatora predstavlja adekvatnost kontrole sigurnosti i zaštite podataka koje tvrtke provode. Porast kršenja zaštite podataka i cyber-napada na istaknute tvrtke, zajedno $\mathrm{s}$ upitnom praksom razmjene podataka (poput one otkrivene $u$ Facebookovom skandalu prikupljanja podataka Cambridge Analytica $)^{6}$ nametnuli su potrebu donošenja novog alata koji će kvalitetnije osigurati zaštitu osobnih podataka pojedinaca. Nova Opća Uredba o zaštiti osobnih podataka (engl. General Data Protection Regulation - GDPR) ${ }^{7}$ pojedincima treba pružiti veći nadzor i stvarnu kontrolu nad njihovim podacima, pravo informiranja o svrsi obrađivanja njihovih podataka, ali i duljini čuvanja njihovih podataka. Uredba pojedincima omogućava i tzv. „pravo na zaborav“" osobnih podataka te nalaže kako pojedinci ne smiju biti predmetom bilo kakvih mjera proizašlih na temelju profiliranja, analize ili predviđanja učinjenih automatskim sredstvima obrade. Nadalje, prema članku 8. Uredbe, djeca su prepoznata kao posebno ranjiva skupina te se u obzir uzima njihova neosviještenost o mogućim rizicima kojima se izlažu (usp. Opća uredba, 2017), s ciljem njihove zaštite od pritiska da podijele osobne podatke bez potpunog poimanja mogućih posljedica. Prema Macenaite (usp. 2017, str. 766), GDPR uredba plod je pokušaja tvoraca politika da se prava pojedinaca na privatnost, a time i dječja, prilagode digitalnoj eri. U tom smislu, osobni podaci djeteta moći će se obraditi u slučaju kada dijete ima najmanje 16 godina, a za djecu niže dobi isključivo uz odobrenje nositelja roditeljske odgovornosti nad djetetom (usp. REGULATION (EU) 2016/679, 2016). Iako je izvorni prijedlog Povjerenstva za GDPR bio priznati i utvrditi jedinstvenu dobnu granicu za dobivanje pristanka

6 Skandal s podacima na Facebooku - Cambridge Analytica bio je veliki politički skandal početkom 2018. godine koji je otkrio da je tvrtka Cambridge Analytica, koja se bavi analizom podataka te je ujedno i radila na kampanji američkog predsjednika Donalda Trumpa, bez njihove suglasnosti prikupila osobne podatke s milijuna profila Facebook korisnika te ih koristila u političke svrhe.

7 Nova uredba je stupila na snagu 24. svibnja 2016. godine, a primjenjuje se izravno u svim državama članica EU-a od 25. svibnja 2018. godine.

8 Tzv. pravo na zaborav nije novotarija GDPR-a već je i ranije definiran u čl. 12 Direktive 95/46/EZ, međutim u GDPR-u se izričito kodificira te se primjenjuje i na tvrtke sa sjedištem izvan EU-a koje imaju poslovni nastan u EU-u. GDPR ide i korak dalje time što teret dokazivanja zadržavanja podataka ostane na voditelju obrade, a ne na pojedincu. Naime, voditelj obrade mora dokazati da mu je neophodno zadržati podatke, u suprotnom ih je dužan obrisati. 
za obradu podataka, u ovom slučaju 13 godina, prijedlog je odbačen te je konačna verzija članka 8. državama članicama omogućila odabir bilo koje minimalne dobi između 13 i 16 godina (usp. Carr, 2017). Prema Macenaite (usp. 2017, str. 768) jasna bi pravila pridonijela stvaranju pravne sigurnosti u vrlo osjetljivoj sferi, tim više što bi zasebna procjena svakog pojedinca, $\mathrm{u}$ administrativnom smislu, bila pretjerano opterećujuća, osobito u digitalnom okruženju. Međutim, prema Lansdownu nije moguće definirati jedinstvenu dobnu granicu koja označava razdoblje kada je djeci potrebna veća ili manja zaštita i kada su sposobni za preuzimanje odgovornosti. Također, smatra kako nije moguće kreirati i uspostaviti pravne i socijalne okvire koji bi bili dovoljno fleksibilni i uključivali različite sposobnosti djece diljem svijeta (usp. Landsdown, 2005 prema Macenaite, 2017, str. 768). Štoviše, uspostava jasne dobne granice mogla bi iz digitalne sfere isključiti djecu koja su sposobna usvojiti zreliji pristup. Naime, prema Konvenciji UN-a o pravima djeteta, razina roditeljskog usmjeravanja ovisit će o evoluirajućim sposobnostima djeteta. Kako ističu Livingstone i suradnici, ograničavanje pristupa internetu za mnogu djecu predstavlja i uskraćivanje mnogobrojnih koristi koje proizlaze iz pristupa internetu, a time dovodi i do nejednakosti u digitalnoj sferi. Internet je postao glavno tehnološko sredstvo kroz koje djeca ostvaruju pristup informacijama i komunikacijskim pravima zaštićenim temeljem Konvencije (usp. Gasser, 2014, str. 118 prema Livingstone, 2017, str. 11). „Implementacija prava djeteta u digitalnoj eri zahtijeva ne samo poštivanje ljudskih prava i vrijednosti, nego i osnaživanje i sudjelovanje dječjih korisnika koje potiče njihovu kreativnost, inovativnost i društveni angažman“ (Linvingstone i sur., 2015, str. 6) $)^{9}$. S druge pak strane, ostvarivanje pristupa internetu u odsutnosti roditelja, odnosno skrbnika ili regulatorne infrastrukture, što je slučaj kod djece koja žive u nepovoljnim uvjetima, može otvoriti put mnogobrojnim opasnostima u odnosu na dobrobiti koje pruža internet (usp. Livingstone, Carr, Byrne, 2015, str. 13). Postavlja se dakle pitanje može li GDPR uredba uspjeti osigurati djetetu UN-ovom Konvencijom zagarantirano pravo na privatnost kao temeljno ljudsko pravo i u online okruženju, balansirajući pritom na adekvatan način online rizike i dobrobiti u skladu s evoluirajućom zrelošću djeteta (usp. Macenaite, 2017, str. 768) ili je pak riječ o ograničavanju prava djeteta? Naime, s obzirom na to da je razvoj interneta, alata kojim djeca i maloljetnici ostvaruju svoje pravo za informiranjem i socijalizacijom, ujedno doveo i do porasta rizika i ugroze njihove sigurnosti, nameće se važnost uključenosti roditelja u virtualnu komunikaciju, a time i njihovog medijskog opismenjavanja, kako bi što aktivnije mogli pratiti medijske aktivnosti svoje djece u online okruženju.

9 Citat u prijevodu. 


\section{Medijski odgoj}

Novi mediji predstavljaju izazove za obitelj u kontekstu održanja interpersonalnih odnosa, budući da je generacijski jaz među njenim članovima sve izraženiji, a njegovo razumijevanje (Popović, 2012) doprinosi preispitivanju vlastitih odnosa prema (novim) medijima, ističe Kanižaj (usp. 2015, str. 38-40).

Posljednje istraživanje o sigurnosti djece i mladih na internetu u Hrvatskoj ${ }^{10}$ na uzorku od 1017 djece u dobi od 9 do 17 godina pokazalo je kako trećina mladih komunicira s osobama koje ne poznaje, a i da se svaki četvrti tinejdžer sastao s osobom koju je upoznao/la online. Iako im je internet glavno sredstvo socijalizacije, neznanje o sigurnom korištenju istoga uzrok je prakticiranju rizičnih ponašanja. Naime, gotovo 3/4 djece vidjelo je pornografske sadržaje unatoč činjenici da ih nisu tražili, što upućuje na njihovu laku dostupnost. Također, uočena je razlika u roditeljskom nadzoru u korist mlađe djece u odnosu na stariju djecu (usp. Kovačević, 2017). Iako je suradnja odgojno-obrazovne ustanove s roditeljima važan dio edukativnog procesa $u$ kontekstu jačanja medijskih kompetencija djece $\mathrm{i}$ roditelja, Visković i Višnjić Jevtić ističu kako je aktualna situacija daleko od partnerstva (usp. 2017, str. 118), ponajviše zbog jednosmjerne komunikacije (usp. Ivaštanin, Vrbanec, 2015, str. 25).

Mediji su postali ozbiljna konkurencija učiteljima i odgajateljima/roditeljima u odgoju i obrazovanju, stoga potreba za medijskim odgojem postaje sve izraženija. Uloga medija ne smije se izostaviti, ali ona ne smije potisnuti onu primarnu - roditeljsku ulogu, naglašava Labaš (usp. 2015, str. 61). Pomak komunikacije djece predškolske i školske dobi od tradicionalnih ka dominantno novim medijima pokazuje nužnost opismenjavanja za digitalne vještine te uključenosti roditelja u virtualnu komunikaciju (usp. Labaš, 2017, str. 40), umjesto njihovog demoniziranja, ističe Labaš (usp. Pelosi prema Labaš, 2015, str. 66-67). To je osobito važno ako uzmemo u obzir ranije spomenute rizike komunikacije na društvenim mrežama (usp. Pezo, 2010, str. 81; usp. Labaš, 2015, str. 67). Nadzor i savjetovanje djece $u$ virtualnom svijetu, posebice za izgovoreno i napisano, danas su imperativ, no roditelji ne smiju biti špijuni svoje djece, upozorava Labaš, već ravnopravni

10 Istraživanje je provedeno u listopadu i studenome 2017. godine u sklopu međunarodnog projekta EU Kids Online u organizaciji Društva za komunikacijsku i medijsku kulturu (DKMK), Agencije za elektroničke medije (AEM) Hrvatskog telekoma (HT), Hrvatske regulatorne agencije za mrežne djelatnosti (HAKOM), Centra za sigurniji Internet (CSI) te agencije Ipsos Puls. Istraživanje su poduprli Ministarstvo znanosti i obrazovanja (MZO) te Ministarstvo za demografiju, obitelj, mlade i socijalnu politiku (MDOMSP). Uz djecu u istraživanju su sudjelovali i roditelji, posebice oni članovi obitelji koji više nadziru aktivnosti djece na internetu. 
partneri kojima će se djeca povjeravati, budući da „odgoj komunicira, a komunikacija odgaja - pa i za ispravno i korisno služenje medijima“" (2015, str. 68).

Odgoj za nove medije ima dvije zadaće: 1) ponuditi nove odgojne metode za nove medije i 2) jačati ulogu odgovornosti (usp. Rivoltella, 2008 prema Labaš, 2017, str. 34). Brojna istraživanja o ponašanju mladih $u$ konzumaciji medija pokazuju njihovu neodlučnost $i$ neopreznost (usp. Mandarić, 2012; Gospodnetić, Morić, 2014; Robotić, 2015), pa Labaš zaključuje kako je „djeci, ali i roditeljima i posebno učiteljima potrebno pružiti prikladne 'alate' kako bi mogli demistificirati i dekonstruirati medije te kako bi stekli dovoljno znanja iz područja medijskog odgoja i medijske pismenosti“ (2015, str. 35). Medijski odgoj ne smije biti samo tehnicističke, već formativne i odgojne naravi, zaključuje Labaš, nadajući se da će to poslužiti i kao okvir za jačanje koncepta digitalne medijske pismenosti (usp. 2017, str. 42).

\section{Metodološki okvir istraživanja}

Istraživanjem je analizirana zaštita privatnosti djece i maloljetnika na društvenoj mreži Facebook iz perspektive roditelja. Ciljevi istraživanja bili su ispitati korisničke preferencije društvene mreže Facebook kod roditeljske populacije te ispitati njihovu svjesnost o rizicima komunikacije na Facebooku. Nadalje, nastojalo se analizirati znanje roditelja o mogućnosti zaštite (sebe i drugih) u komunikaciji na društvenoj mreži Facebook te konačno ispitati upoznatost roditelja s novom Općom uredbom EU-a o zaštiti osobnih podataka (GDPR). Na temelju definiranih ciljeva istraživanja postavljene su sljedeće hipoteze:

$H_{1}$ : Roditelji koriste društvenu mrežu Facebook svakodnevno, a najčešće objavljuju vlastite fotografije i fotografije iz obiteljskog života koje uključuju i djecu.

$\mathrm{H}_{2}$ : Roditelji nisu svjesni rizika komuniciranja na društvenoj mreži Facebook (zloupotreba osobnih podataka, zaštita vlastitog identiteta, zaštita djece i maloljetnika).

$H_{3}$ : Roditelji su upoznati s mehanizmima zaštite (sebe i drugih) u komunikaciji na društvenoj mreži Facebook.

$H_{4}$ : Roditelji nisu u potpunosti upoznati s novom Općom uredbom EU-a o zaštiti osobnih podataka (GDPR). 
Istraživanje je provedeno u studenome 2017. godine u periodu od 14 dana (7. 11. 2017. - 21 . 11. 2017.) na namjernom uzorku (uzorak lančane reakcije) (Tkalac Verčič i sur., 2014, str. 77) od 160 roditelja grada Zagreba. Za prikupljanje podataka korištena je metoda ankete provedena online putem, prigodno putem društvene mreže Facebook.

\subsection{Interpretacija rezultata istraživanja}

Struktura uzorka istraživanja pokazuje tri puta veću zastupljenost žena (75 \%) u odnosu na muškarce (25 \%). Najveći dio ispitanika čine roditelji u dobi od 30. do 39. godine života (68 \%), dok najmanje ima onih najmlađih roditelja u dobi do 29. godine života (3\%). Svoj Facebook profil više puta dnevno provjerava 66 \% ispitanika. Roditelja koji Facebook provjeravaju jednom dnevno ima $20 \%$, a više puta tjedno provjerava ga njih $8 \%$. Jednom tjedno to čini njih $5 \%$, a samo jednom mjesečno to čini njih $2 \%$ (Tablica 1 ).

Tablica 1. Učestalost provjeravanja Facebook profila $(\mathrm{N}=160)$

\begin{tabular}{|c|c|c|c|c|c|c|c|c|c|}
\hline \multicolumn{2}{|c|}{$\begin{array}{l}\text { Više puta } \\
\text { dnevno }\end{array}$} & \multicolumn{2}{|c|}{ Jednom dnevno } & \multicolumn{2}{|c|}{ Jednom tjedno } & \multicolumn{2}{|c|}{ Više puta tjedno } & \multicolumn{2}{|c|}{$\begin{array}{l}\text { Jednom } \\
\text { mjesečno }\end{array}$} \\
\hline $\mathrm{f}$ & $\%$ & $\mathrm{f}$ & $\%$ & $\mathrm{f}$ & $\%$ & f & $\%$ & $\mathrm{f}$ & $\%$ \\
\hline 105 & 66 & 32 & 20 & 8 & 5 & 12 & 8 & 3 & 2 \\
\hline
\end{tabular}

Ispitanici izjavljuju kako na svom Facebook profilu najčešće objavljuju zanimljive ili humoristične sadržaje. Na drugom mjestu je objavljivanje obiteljskih fotografija koje uključuju djecu. Slijede razne tuđe objave, zatim osobne fotografije te na posljednjem mjestu video zapisi (Tablica 2).

Tablica 2. Najčešće objavljivani sadržaji na Facebook profilu (N=160)

\begin{tabular}{|c|c|c|c|c|c|c|c|c|c|}
\hline \multicolumn{2}{|c|}{$\begin{array}{l}\text { Osobne } \\
\text { fotografije }\end{array}$} & \multicolumn{2}{|c|}{$\begin{array}{l}\text { Obiteljske } \\
\text { fotografije } \\
\text { (suprug/a, partner/ } \\
\text { ica, djeca, roditelji) }\end{array}$} & \multicolumn{2}{|c|}{ Video zapisi } & \multicolumn{2}{|c|}{$\begin{array}{l}\text { Zanimljivi ili } \\
\text { humoristični } \\
\text { sadržaji }\end{array}$} & \multicolumn{2}{|c|}{$\begin{array}{l}\text { Razne tuđe objave } \\
\text { (tuđe proslijeđene } \\
\text { fotografije ili } \\
\text { postovi, lančane } \\
\text { objave, molbe, } \\
\text { žalbe, video zapisi) }\end{array}$} \\
\hline $\mathrm{f}$ & $\%$ & $\mathrm{f}$ & $\%$ & $\mathrm{f}$ & $\%$ & $\mathrm{f}$ & $\%$ & $\mathrm{f}$ & $\%$ \\
\hline 30 & 19 & 39 & 24 & 14 & 9 & 87 & 54 & 35 & 22 \\
\hline
\end{tabular}


Najviše ispitanika ima djelomično javan profil. Slijede oni s potpuno privatnim postavkama privatnosti te jedan manji udio onih kojima su postavke privatnosti u potpunosti javne (Tablica 3).

Tablica 3. Postavke privatnosti Facebook profila kod ispitanika $(\mathrm{N}=160)$

\begin{tabular}{|c|c|c|c|c|c|}
\hline \multicolumn{2}{|c|}{ U potpunosti javne } & \multicolumn{2}{|c|}{ Djelomično javne } & \multicolumn{2}{|c|}{ U potpunosti privatne } \\
\hline f & $\%$ & $\mathrm{f}$ & $\%$ & $\mathrm{f}$ & $\%$ \\
\hline 20 & 13 & 73 & 46 & 67 & 42 \\
\hline
\end{tabular}

Promjene u postavkama privatnosti Facebooka redovito prati 39 \% ispitanika, dok $61 \%$ ispitanika promjene postavki privatnosti ne prati. Nadalje, gotovo $71 \%$ ispitanika nema nikakvo saznanje o navedenoj novoj Općoj uredbi EU-a o zaštiti osobnih podataka, a 29 \% ispitanika ima neka saznanja. Ukupno 96 \% ispitanika uvjereno je da nikada nije povrijedilo, ni namjerno ni slučajno, tuđe pravo privatnosti na društvenoj mreži Facebook u smislu zlouporabe tuđih osobnih podataka ili privatnih sadržaja, dok ih se $4 \%$ izjasnilo da je to učinilo. Istodobno, $20 \%$ ispitanika označava druge osobe na fotografijama i prijavljuje ih na raznim lokacijama, bez prethodne provjere s njima, a ostali tvrde da to ne čine. Više od polovice ispitanika objavljuje fotografije vlastite djece na Facebooku. Naime, čak 80 \% roditelja potvrdilo je da ne traži dopuštenje svoje djece za objavu njihovih fotografija na Facebooku, dok dopuštenje traži njih svega $20 \%$.

Najviše ispitanika preferira objavljivanje fotografija koje djecu prikazuju u punom profilu tako da im je identitet otkriven. Slijede oni koji prikazuju djecu u poluprofilu tako da im je identitet djelomično otkriven. Znatno je manje onih ispitanika čije fotografije prikazuju djecu s leđa ili djetetove osobne predmete, tako da im je identitet skriven (Tablica 4). 


\begin{tabular}{|c|c|c|c|c|c|c|c|c|c|}
\hline \multicolumn{2}{|c|}{$\begin{array}{l}\text { Fotografija } \\
\text { uvijek prikazuje } \\
\text { dijete/djecu s } \\
\text { leđa (identitet } \\
\text { skriven) }\end{array}$} & \multicolumn{2}{|c|}{$\begin{array}{l}\text { Fotografija } \\
\text { prikazuje } \\
\text { dijete/djecu } \\
\text { u poluprofilu } \\
\text { (identitet } \\
\text { djelomično } \\
\text { otkriven) }\end{array}$} & \multicolumn{2}{|c|}{$\begin{array}{l}\text { Fotografija } \\
\text { prikazuje } \\
\text { dijete/djecu u } \\
\text { punom profilu } \\
\text { (identitet javan) }\end{array}$} & \multicolumn{2}{|c|}{$\begin{array}{l}\text { Fotografija } \\
\text { prikazuje } \\
\text { djetetove } \\
\text { osobne } \\
\text { predmete }\end{array}$} & \multicolumn{2}{|c|}{ Ostalo } \\
\hline $\mathrm{f}$ & $\%$ & $\mathrm{f}$ & $\%$ & $\mathrm{f}$ & $\%$ & $\mathrm{f}$ & $\%$ & f & $\%$ \\
\hline 4 & 4 & 18 & 19 & 69 & 73 & 2 & 2 & 1 & 1 \\
\hline
\end{tabular}

Kada je riječ o percepciji rizika na društvenim mrežama najveći udio ispitanika smatra da su to pedofilija (22 \%) i cyberbullying (21\%), a slijede oni koji smatraju da je to povreda duševnog integriteta (19 \%). U značajno manjim udjelima rizika percipirani su govor mržnje (14 \%) i trgovanje ljudima (13\%). Zanemariv je udio ispitanika koji medijsko iskorištavanje djece i sexting svrstavaju u rizike (Tablica 5).

Tablica 5. Rizici komunikacije na društvenim mrežama ( $N=160)$

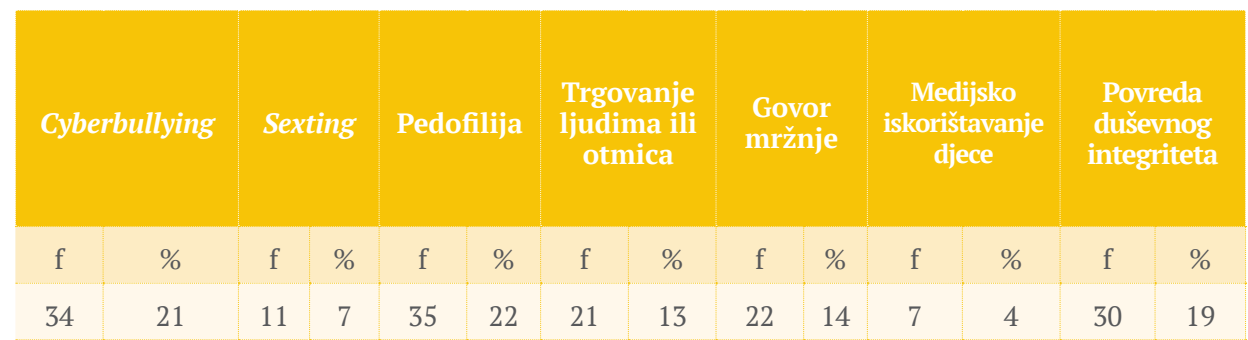

Većina ispitanika (75 \%) odgovorila je da njihova djeca nemaju svoj Facebook profil, dok njih 25 \% kaže da imaju. Kada je riječ o dobi djece ispitanika prilikom otvaranja Facebook profila, većina je njih to učinila prije 13. godine. Dakle, puno prije ograničenja koja stavljaju i Facebook i GDPR uredba. S 13 godina profil je otvorilo njih $28 \%$, a sa starijom životnom dobi opada i otvaranje Facebook profila kod djece (Tablica 6). 
Tablica 6. Dob djece ispitanika prilikom otvaranja Facebooka (N=40)

\begin{tabular}{|c|c|c|c|c|c|c|c|c|c|}
\hline \multicolumn{2}{|c|}{ prije 13 . godine } & \multicolumn{2}{|c|}{ s 13 godina } & \multicolumn{2}{|c|}{ sa 14 godina } & \multicolumn{2}{|c|}{ s 15 godina } & \multicolumn{2}{|c|}{ sa 16 godina } \\
\hline f & $\%$ & f & $\%$ & $\mathrm{f}$ & $\%$ & f & $\%$ & f & $\%$ \\
\hline 21 & 53 & 11 & 28 & 5 & 13 & 1 & 3 & 2 & 5 \\
\hline
\end{tabular}

Većina roditelja (90 \%) slaže se s GDPR uredbom prema kojoj djeca ne mogu pristupiti društvenim mrežama ako su mlađa od 13, odnosno 16 godina bez pristanka roditelja. Od onih koji ne podupiru Uredbu, većina njih kaže da je Uredba beskorisna s obzirom na to da dijete može lažirati svoju dob i time izbjeći pristanak i nadzor roditelja. Nadalje, $19 \%$ roditelja iskreno je priznalo da nema dovoljnu razinu znanja o društvenim mrežama te da ne mogu ni odobriti ni zabraniti svojoj djeci pristup određenim sadržajima, dok $9 \%$ njih smatra da se pretjeranom kontrolom zadire $u$ privatnost djece i gubi njihovo povjerenje (Tablica 7).

Tablica 7. Razlozi neslaganja s GDPR uredbom (N=32)

Ne posjedujem dovoljnu razinu znanja o društvenim

mrežama pa nisam u

mogućnosti odobriti/ zabraniti pristup

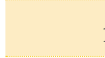

f

6

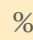

19
Uredba je beskorisna jer

dijete može lažirati svoju

dob i time izbjeći pristanak

i nadzor
Pretjeranom kontrolom

zadirem u privatnost svog

djeteta i gubim njegovo povjerenje

\begin{tabular}{|l|l|l|l|l|l|}
\hline f & \% & f & $\%$ & f & $\%$ \\
\hline 6 & 19 & 24 & 75 & 3 & 9 \\
\hline
\end{tabular}

Većina roditelja koji su izrazili slaganje s GDPR uredbom njenu korist vide u suzbijanju opasnosti na društvenim mrežama koju djeca i maloljetnici ne znaju prepoznati. Nadalje, roditelji su svjesni da su oni ti koji su odgovorni za ponašanje svoje djece te moraju biti uključeni i u njihov medijski odgoj. Također, roditelji smatraju da je Uredba važna jer ona uređuje način sudjelovanja djece i maloljetnika na društvenim mrežama. (Tablica 8).

Tablica 8. Razlozi slaganja s GDPR uredbom ( $\mathrm{N}=135)$

Roditelji su odgovorni za

ponašanje svoje djece do

punoljetnosti, a to uključuje

i ponašanje na društvenim mrežama
Na društvenim mrežama

ima puno opasnosti koje

djeca i maloljetnici ne znaju

prepoznati
Regulativa uređuje način

sudjelovanja djece i

maloljetnika na društvenim mrežama

\begin{tabular}{|c|c|c|c|c|c|}
\hline f & $\%$ & f & $\%$ & f & $\%$ \\
\hline 56 & 41 & 92 & 68 & 10 & 7 \\
\hline
\end{tabular}


Većina roditelja prakticira razgovor s djecom o komunikaciji na Facebooku, dok $44 \%$ roditelja ne prakticira razgovor s djecom na tu temu. Od onih koji razgovaraju s djecom, najviše njih (64 \%) to čini jer žele upozoriti dijete na opasnosti društvenih mreža. Slijede oni koji žele upoznati dijete s pravilima korištenja društvenih mreža (33 \%). Gotovo podjednak je udio onih koji žele upoznati svoje dijete s mogućnostima i ograničenjima Facebooka te znati je li njihovo dijete imalo neugodna iskustva na Facebooku (22 \%). Samo 10 \% njih potvrdilo je da nije zadovoljno znanjem o medijima koje djeca stječu u školi (Tablica 9).

Tablica 9. Razlozi razgovaranja s djecom o komunikaciji na Facebooku (N=90)

\begin{tabular}{|c|c|c|c|c|c|c|c|c|c|}
\hline \multicolumn{2}{|c|}{$\begin{array}{l}\text { Želim upoznati } \\
\text { svoje dijete s } \\
\text { mogućnostima } \\
\text { i ograničenjima } \\
\text { Facebooka } \\
\text { kao društvene } \\
\text { mrě̌e }\end{array}$} & \multicolumn{2}{|c|}{$\begin{array}{l}\text { Želim znati je } \\
\text { li moje dijete } \\
\text { imalo neugodna } \\
\text { iskustva u } \\
\text { komunikaciji } \\
\text { na društvenoj } \\
\text { mreži Facebook }\end{array}$} & \multicolumn{2}{|c|}{$\begin{array}{l}\text { Nisam } \\
\text { zadovoljan } \\
\text { znanjem o } \\
\text { medijima koje } \\
\text { moje dijete } \\
\text { stječe u školi }\end{array}$} & \multicolumn{2}{|c|}{$\begin{array}{l}\text { Želim svoje } \\
\text { dijete upozoriti } \\
\text { na opasnosti } \\
\text { korištenja } \\
\text { društvenih } \\
\text { mreža }\end{array}$} & \multicolumn{2}{|c|}{$\begin{array}{l}\text { Želim svoje } \\
\text { dijete upoznat } \\
\text { s pravilima } \\
\text { korištenja } \\
\text { društvenilh } \\
\text { mreža (pravila } \\
\text { privatnosti } \\
\text { i kultura } \\
\text { ponašanja) }\end{array}$} \\
\hline $\mathrm{f}$ & $\%$ & $\mathrm{f}$ & $\%$ & $\mathrm{f}$ & $\%$ & $\mathrm{f}$ & $\%$ & $\mathrm{f}$ & $\%$ \\
\hline 20 & 22 & 20 & 22 & 10 & 11 & 58 & 64 & 30 & 33 \\
\hline
\end{tabular}

Većina ispitanika potvrdila je da ne prati aktivnosti svoje djece na Facebooku (58 \%). Oni koji ipak prate aktivnosti svoje djece na Facebooku kažu da žele zaštititi dijete od opasnosti u virtualnom svijetu (63 \%). Podjednak je broj onih ispitanika koji žele biti prijatelji, kao i roditelji, svom djetetu i u virtualnom svijetu (25\%) te onih koji žele imati kontrolu nad online komunikacijom svoga djeteta (Tablica 10).

Tablica 10. Razlozi praćenja aktivnosti vlastite djece na Facebooku (N=59)

\begin{tabular}{|c|c|c|c|c|c|}
\hline \multicolumn{2}{|c|}{$\begin{array}{c}\text { Želim biti prijatelj/roditelj } \\
\text { svom djetetu i u virtualnom } \\
\text { svijetu }\end{array}$} & \multicolumn{2}{|c|}{$\begin{array}{l}\text { Želim imati kontrolu nad } \\
\text { online komunikacijom svoga } \\
\text { djeteta }\end{array}$} & \multicolumn{2}{|c|}{$\begin{array}{c}\text { Želim zaštititi dijete od } \\
\text { opasnosti u virtualnom } \\
\text { svijetu }\end{array}$} \\
\hline $\mathrm{f}$ & $\%$ & $\mathrm{f}$ & $\%$ & $\mathrm{f}$ & $\%$ \\
\hline 15 & 25 & 15 & 25 & 37 & 63 \\
\hline
\end{tabular}




\subsection{Osvrt na polazne hipoteze}

Rezultati istraživanja pokazali su kako ispitanici svakodnevno koriste društvenu mrežu Facebook te da višekratno provjeravaju svoj profil, što je i na tragu ranijih istraživanja o korištenju Facebooka kod Hrvata (usp. Vitas, 2016; Kostanić, 2017). Pokazalo se da ispitanici najčešće objavljuju zanimljive ili humoristične sadržaje i obiteljske fotografije koje uključuju i djecu, no vlastite su im fotografije na predzadnjem mjestu od svih ponuđenih opcija. Stoga je prva hipoteza djelomično potvrđena.

Nadalje, utvrđeno je kako roditelji nisu svjesni rizika komuniciranja (Pezo, 2010) na društvenoj mreži Facebook (zloupotreba osobnih podataka, zaštita vlastitog identiteta te zaštita djece i maloljetnika), što potvrđuju nalazi o objavi fotografije vlastite djece, načini njihova prikazivanja, kao i netraženje dopuštenja za objavu istih. Time je druga hipoteza u potpunosti potvrđena.

Kada je riječ o mehanizmima zaštite (sebe i drugih) u komunikaciji na društvenoj mreži Facebook, rezultati su pokazali da roditelji imaju teorijska znanja o navedenome, no u svakodnevnoj praksitone primjenjuju.Neredovito praćenjepromjenau postavkama privatnosti onemogućava ispitanicima dovoljnu zaštitu vlastitoga profila (djelomično ili potpuno javan), budući da ne prate i ne (po)znaju mogućnosti koje im stoje na raspolaganju. Time je treća hipoteza djelomično potvrđena. Iako je većina potvrdila da nikada nisu povrijedili tuđe pravo privatnosti na Facebooku, praksa ih demantira, budući da su potvrdili kako često označavaju druge na fotografijama i lokacijama bez njihove suglasnosti. Posljedica je to generacijskog jaza s jedne strane i nedovoljnog znanja o komunikaciji na digitalnim platformama s druge, što nameće potrebu za jačanjem medijskih kompetencija roditelja (Labaš, 2015; Labaš, 2017) kako bi mogli aktivno pratiti online aktivnosti svoje djece. Konačno, to je i jedan od ciljeva nove uredbe EU-a GDPR prema kojoj je pristup društvenoj mreži Facebook dobno uvjetovan te traži roditeljski pristanak. Većina ispitanika podupire novu uredbu (90 \%), ponajviše zbog pomoći djeci i maloljetnicima u prepoznavanju rizika komunikacije na Facebooku. No, oni koji ju ne podupiru suglasni su oko toga da je uredbu moguće ignorirati lažiranjem dobi korisnika. Time je u potpunosti potvrđena i posljednja četvrta hipoteza istraživanja. Napominjemo kako je provedeno istraživanje pilot istraživanje čiji se rezultati ne mogu generalizirati zbog nereprezentativnog uzorka, ali koje ipak osigurava uvid $\mathrm{u}$ aktualne trendove vezane uz zaštitu osobnih podataka u digitalnom okruženju sukladno novom regulatornom okviru, kao i analizu upoznatosti s njime, te će nesumnjivo poslužiti kao temelj za daljnja proučavanja komunikacije i ponašanja korisnika na društvenim mrežama i zaštite njihove privatnosti. 


\section{Zalključak}

Novi mediji, a posebice društvene mreže, postali su neizostavni dio svakodnevne komunikacije svih generacija - roditelja i djece, usprkos izraženim razlikama u poznavanju rizika komunikacije na istima, ali i (ne)poznavanju tehničko-sigurnosnih komponenti upravljanja vlastitim profilima. I dok jedni broj virtualnih prijatelja promatraju kroz dimenziju socijalnoga kapitala (usp. Krolo, 2015), drugi upozoravaju na moguće negativne učinke online komunikacije u interpersonalnim odnosima (usp. Pavić, Šundalić, 2015). Društvene mreže postale su digitalni dnevnici, pri čemu se zanemaruje pitanje zaštite privatnosti osoba koje su na fotografijama pojedinoga profila ili se iste objavljuju bez njihova znanja i pristanka. Riječ je o skupini rizika kojoj su najviše izložena djeca i maloljetnici, a kojima ih (ne)svjesno izlažu njihovi roditelji neodgovornim ponašanjem na društvenim mrežama.

Porast broja empirijskih podataka o upotrebi interneta i rizicima kod djece te o broju mobilnih aplikacija za brojne internetske servise i društvene mreže kojima pristupaju sve mlađa djeca potaknuo je i EU na promjenu postojećeg regulatornog okvira te usvajanje Opće uredbe o zaštiti osobnih podataka (GDPR). Nedostatak konsenzusa unutar EU-a oko jedinstvene dobne granice za pristup društvenim mrežama (od 13 do 16 godina) posljedica je razlika u drugim sektorima poput istraživanja tržišta i oglašavanja, ali i nacionalnih zakonodavstava (usp. Macenaite, Kosta, 2017, str. 152, 164). Osim sporne dobne granice, koja je postala predmetom kritika javnosti, ističu se i ostali problemi praktične primjene: 1) porast nesigurnosti $u$ informacijskom društvu zbog upitne budućnosti besplatnih internetskih servisa, 2) definiranje oblika zaštite koju internetski servisi trebaju nuditi, 3) kako riješiti pitanje roditeljskog pristanka kada je roditeljska skrb na drugim pojedincima ili ostalim zakonskim skrbnicima?, 4) kako dokumentirati i dokazati roditeljski pristanak?, 5) konkretnije definirati specifične mehanizme roditeljskog pristanka, 6) nužnost detaljnije verifikacije roditeljskog pristanka (usp. Macenaite, Kosta, 2017, str. 195). Komunikacija u digitalnoj sferi mora biti temeljena na povjerenju kao preduvjetu kvalitetnijih odnosa, posebice između roditelja i djece, no pritom je važno da roditelji osvijeste razliku između vodstva i kontrole (usp. Dokler, 2017), ali i porade na jačanju digitalnih kompetencija za komuniciranje na društvenim mrežama. 
$\mathrm{Na}$ temelju provedenog istraživanja, doduše na uzorku koji nije reprezentativan, koje je pokazalo nedovoljnu osviještenost roditelja o zaštiti privatnosti djece i maloljetnika na društvenoj mreži Facebook te njihovu neupoznatost s detaljima GDPR uredbe važno je provesti sljedeće:

Osvijestiti roditelje o sigurnosnim rizicima na društvenim mrežama. Rezultati našeg istraživanja pokazali su različitu percepciju rizika kod roditeljske populacije (medijsko iskorištavanje djece, govor mržnje i sexting slabo su prepoznati) što je odraz nedovoljnog poznavanja digitalnih kompetencija kod roditelja (usp. Labaš, 2015; Labaš, 2017).

Informirati roditelje o važnosti uključenosti u online aktivnosti njihove djece na društvenim mrežama kao doprinos razvoju medijskog odgoja u digitalnoj sferi. Iako većina roditelja (više od 80 \%) prema našem istraživanju postavlja granice kada je u pitanju korištenje digitalnih medija, istodobno više od 40 \% njih ne prati aktivnosti svoje djece na Facebooku ili pak ne komunicira o istome s njima, ostavljajući djeci da se sami nose s izazovima digitalnog doba (usp. Labaš, 2015; Labaš, 2017).

\section{Kreirati komunikacijsku kampanju o GDPR uredbi i njenoj implementaciji u suradnji} s medijima. Naime, primjena GDPR uredbe i njeni učinci nisu dovoljno zastupljeni u medijskim sadržajima, već se analiza provodi s marketinškog aspekta. Istodobno, zanemarena je uloga djece i maloljetnika te zaštite njihovih prava u komunikaciji na društvenim mrežama (usp. Livingstone, O’Neill, 2014), što otvara put za djelovanje i analizu implementacije.

Navedene smjernice nužne su zbog aktivnog uključivanja roditelja u proces digitalnog opismenjavanja kako bi mogli pratiti aktivnosti vlastite djece na digitalnim platformama, te kako bi sami odgovorno komunicirali na istima čuvajući vlastitu privatnost, ali i privatnost svoje djece sukladno novoj Općoj uredbi o zaštiti osobnih podataka koja je stupila na snagu. 


\section{Popis literature}

- Boban, M. (2012). Pravo na privatnost i pravo na pristup informacijama u suvremenom informacijskom društvu, 575-598. U: Zbornik radova Pravnog fakulteta u Splitu. 49 (3), Split: Pravni fakultet Sveučilišta u Splitu.

- Ciboci, L., Kanižaj, I., Labaš, D. (2014). Media Education form the Perspective of Parents of Preshool Children: Challenges and Trends in Free Time Media Use. Medijska istraživanja, 20 (2), 53-67.

- Ciboci, L. (2015). Od medijskog opismenjavanja do odgovornog roditeljstva, 46-53. U: Komunikacija odgaja-odgoj komunicira. Emocionalna i medijska pismenost. Zagreb: Pragma (Zagreb: Kerschoffset).

- De Vito, J. (2016). The Interpersonal Communication Book (fourteenth edition). Pearson: Global Edition.

- Dragojević, S. (1995). Utjecaj kulturnog, društvenog i simboličkog kapitala na razvoj zemalja Srednje i Istočne Europe. Revija za sociologiju, XXVI (3-4), 177-188.

- Dokman, T., Kuzelj, M., Malnar, D. (2018). Društvene mreže u ulozi modernog oružja - percepcija doktoranada. Polemos: časopis za interdisciplinarna istraživanja rata i mira, XXI (41), 133-150.

- Gabelica Šupljika, M. (2009). Psihološki aspekt prikaza djeteta u medijima, 19-33. U: Flego, M. (ur.), Zaštita privatnosti djece u medijima, Zbornik priopćenja s tribine. Zagreb: Pravobranitelj za djecu.

- Ivaštanin, I., Vrbanec, D. (2015). Razvijanje partnerstva s roditeljima. Dijete, vrtić, obitelj, 21 (79), 24-25.

- Jelavić, M. (2009). Djeca u medijima: Kako im osigurati zaštitu privatnosti? Iskustva Ureda pravobraniteljice za djecu, 7-19. U: Flego, M. (ur.), Zaštita privatnosti djece u medijima, Zbornik priopćenja s tribine. Zagreb: Pravobranitelj za djecu.

- Kanižaj, I. (2015). Mediji, obitelj i komunikacija, 38-44. U: Komunikacija odgaja - odgoj komunicira. Emocionalna i medijska pismenost. Zagreb: Pragma (Zagreb: Kerschoffset).

- Krolo, K. (2015). Facebook prijatelji kao pokazatelj strukturnih dimenzija društvenog kapitala mladih u Hrvatskoj. Revija za sociologiju, 45 (2), 145-170.

- Krolo, K., Puzek, I. (2014): Upotreba internetskih društvenih mreža i participacijske dimenzije društvenoga kapitala mladih na primjeru Facebooka. Društvena istraživanja: časopis za opća društvena pitanja, 23 (3), 383-405.

- Kušić, S. (2010). Online društvene mreže i društveno umrežavanje kod učenika osnovne škole: navike Facebook generacije. Život i škola, 56 (24), 103-125.

- Labaš, D. (2015). Komunikacija odgaja - odgoj komunicira. Prijedlozi i smjernice za roditeljski medijski odgoj, 61 - 68. U: Komunikacija odgaja - odgoj komunicira. Emocionalna i medijska pismenost. Zagreb: Pragma (Zagreb: Kerschoffset).

- Labaš, D. (2017). Medijska pismenost i informacijsko doba, 31-46. U: Josić, Lj. (ur.), Zbornik Informacijska tehnologija i mediji 2016. Zagreb: Hrvatski studiji Sveučilišta u Zagrebu, Biblioteka Informacijska tehnologija i mediji.

- Livingstone, S., O’Neill, B. (2014). Children's Rights Online: Challenges, Dilemmas and Emerging Directions, 19-38. U: Van der Hof, S. i sur. (ur.), Minding Minors Wandering the Web: Regulating Online Child Safety, Information Technology and Law Series (24), Springer with T. M. C. Asser Press, The Hague, The Netherlands. DOI: 10.1007/978-94-6265-005-3_2.

- Livingstone, S., Carr, J., Byrne, J. (2015). One in Three: Internet Governance and Children's Rights, 1-32. Global Commission on Internet Governance, 22.

- Macenaite, M. (2017). From universal towards child-specific protection of the right to privacy online: Dilemmas in the EU General Data Protection Regulation. New Media \& Society 2017, 19 (5), 765-779.

- Macenaite, M., Kosta, E. (2017). Consent for processing children's personal data in the EU: following in US footsteps? Information \& Communication Technology Law, 26 (2), 146-197.

- Majetič, F., Rajter, M., Dević, M. (2017). Razlike u društvenom kapitalu stanovništva Hrvatske s obzirom na stupanj urbaniziranosti naselja stanovanja. Revija za sociologiju, 47 (1), 37-63.

- Mandarić, V. (2012). Novi mediji i rizično ponašanje djece i mladih. Bogoslovska smotra, 82 (1), 131-149.

- Mučalo, M., Šop, S. (2008). Nova publika novih medija. Informatologia, 41 (1), 51-55.

- Nikodem, K. (2003). Čiji su to svjetovi iza nas? Virtualna stvarnost i ljudski identiteti. Socijalna ekologija, 12 (3-4), 211-229.

- Pavić, Ž., Šundalić, A. (2015). Internet social networks, social capital, and political participation. Media, culture and public relations, 6 (2), 128-138.

- Pezo, A. (2010). Uloga odraslih u zaštiti djece na internetu, 79-86. U: Flego, M. (ur.), Dječja prava i slobodno vrijeme, Zbornik 
priopćenja s tribina pravobraniteljice za djecu. Zagreb: Pravobranitelj za djecu (Nedelišće: Tamposit).

- Popović, I. (2012). Problemi međugeneracijske komunikacije zbog utjecaja društvenih mreža. Informatologia, 45 (4), 333-341.

- Reardon, K. (1998). Interpersonalna komunikacija, Zagreb: Alineja.

- Robotić, P. (2015). Zamke virtualnog svijeta: zaštita djece i mladih na internetu i prevencija ovisnosti. Journal of Applied Health Sciences $=$ Časopis za primijenjene zdravstvene znanosti, 1 (2), 81-96.

- Sindik, J. (2008). Kako roditelji percipiraju utjecaj medija na predškolsku djecu? Medijska istraživanja, 18 (1), 5 - 32.

- Tkalac Verčič, A., Sinčić Ćorić, D., Pološki Vokić, N. (2014). Priručnik za metodologiju istraživačkog rada u društvenim istraživanjima: kako osmisliti, provesti i opisati znanstveno ili stručno istraživanje. Zagreb: M.E.P. (Zagreb: Kerschoffset).

- Tomić-Koludrović, I. (2007). Društveni angažman hrvatskih građana i građanki kao indikator društvenog kapitala. Acta Iadertina, 4, 51-78.

- Valković, J. (2016). Utjecaj medija na socijalizaciju. Riječki teološki časopis, 47 (1), 99-116.

- Visković, I., Višnjić Jevtić, A. (2017). Theacer’s Opinions on the Possibilities of Collaboration with Parents. Croatian Journal of Education, 19 (1), 117-146.

- Zgrabljić Rotar, N. (2017). Novi mediji digitalnog doba, 57-64. U: Josić, Lj. (ur.), Zbornik Informacijska tehnologija i mediji 2016. Zagreb: Hrvatski studiji Sveučilišta u Zagrebu, Biblioteka Informacijska tehnologija i mediji.

- Zgrabljić Rotar, N. (2009). Pravo na privatnost: Standardi za zaštitu privatnosti djece u medijima, 34-45. U: Flego, M. (ur.), Zaštita privatnosti djece u medijima, Zbornik priopćenja s tribine. Zagreb: Pravobranitelj za djecu.

\section{Internetski izvori}

- Carr, J. (2017). The position of children and their rights under the GDPR.. Media Policy Project Blog. Dostupno na: http:// blogs.lse.ac.uk/mediapolicyproject/2017/05/22/the-position-of-children-and-their-rights-under-the-gdpr/. Preuzeto 6. prosinca 2017.

- Dokler, A. (2017). Prijatelji sa svojim djetetom na Facebooku: da ili ne? Dostupno na: http://www.medijskapismenost.hr/ prijatelji-svojim-djetetom-facebooku-da-ne/. Preuzeto 9. listopada 2017.

- Gospodnetić, F., Morić, D. (2014). Mladi i mediji, Zagreb: Forum za slobodu odgoja. Dostupno na: http://www.fso.hr/wpcontent/uploads/2015/12/Moric-Gospodnetic-Mladi-i-mediji-pb.pdf. Preuzeto 22. studenoga 2017.

- Kostanić, A. M. (2017). Hrvati na Facebooku: Ulogirani su cijelo vrijeme i imaju stotine prijatelja. Dostupno na: https://zimo. dnevnik.hr/clanak/hrvati-na-facebooku-ulogirani-su-cijelo-vrijeme-i-imaju-stotine-prijatelja---485642.html. Preuzeto 15. studenoga 2017.

- Kovačević, L. (2017). Pornografski sadržaj vidi tri četvrtine djece. Dostupno na: https://www.vecernji.hr/vijesti/internetmladi-online-igor-kanizaj-1209150. Preuzeto 22. studenoga 2017.

- Mudražija, M. (2017). Privatnost djece i mladih u svijetu modernih tehnologija (interneta i društvenih mreža). Koliko smo sigurni i kako zaštiti svoju privatnost i osobne podatke, Zagreb: AZOP. Dostupno na: http://azop.hr/images/dokumenti/217/brosuraprivatnost-djece.pdf. Preuzeto 5. prosinca 2017.

- Regulation (EU) 2016/679 Official Journal of the Euoropean Union (2016). Dostupno na: http://eur-lex.europa.eu/legal-content/ EN/TXT/PDF/?uri=CELEX:32016R0679\&from=E. Preuzeto 6. prosinca 2017.

- Opća uredba (2017). Dostupno na: http://azop.hr/images/dokumenti/217/letak-opca-uredba.pdf. Preuzeto 6. prosinca 2017.

- Vitas, Z. (2016). U Hrvatskoj je više od 1,9 milijuna ljudi aktivno na Facebooku. Dostupno na: https://www.vecernji.hr/techsci/uhrvatskoj-je-vise-od-19-milijuna-ljudi-aktivno-na-facebooku-1132516. Preuzeto 21. studenoga 2017.

- Poliklinika za zaštitu djece i mladih grada Zagreba (2014). Istraživanje o iskustvima i ponašanjima djece na Internetu i na društvenoj mreži Facebook. Dostupno na http://www.poliklinika-djeca.hr/istrazivanja/istrazivanje-o-iskustvima-i-ponasanjimadjece-na-internetu-i-na-drustvenoj-mrezi-facebook-2/. Preuzeto 5. prosinca 2017. 


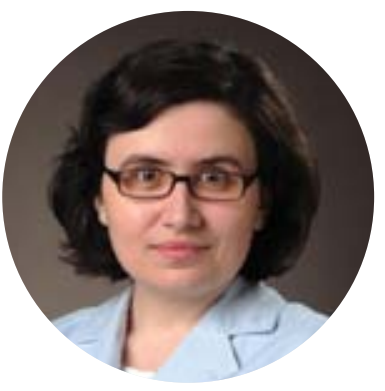

\section{Tanja Grmuša}

Doc. dr. sc. Tanja Grmuša voditeljica je Katedre studija marketinga i komunikacija Poslovnog veleučilišta Zagreb gdje izvodi nastavu iz područja komunikologije, metodologije, medija, poslovne komunikacije i menadžmenta na preddiplomskim stručnim studijima Marketinga i komunikacija, Menadžmenta i produkcije u kulturi te Upravljanja opskrbnim lancima te na specijalističkom diplomskom stručnom studiju Marketinga $i$ komunikacija. Suradnica je Odsjeka za komunikologiju Hrvatskih studija Sveučilišta u Zagrebu. Sudjelovala je na brojnim domaćim i međunarodnim simpozijima, znanstvenim i stručnim konferencijama te je objavila desetak radova. Urednica je nekoliko zbornika radova i knjiga sažetaka međunarodne znanstveno-stručne konferencije iz područja marketinga i komunikacija.

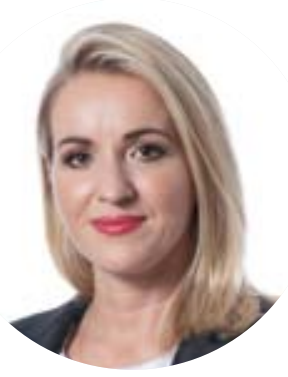

\section{Ana Marguerite Tomulić}

Ana Marguerite Tomulić zaposlenica je Hrvatske gospodarske komore, gdje asistira glavnoj tajnici Nacionalnog odbora Međunarodne trgovačke komore (ICC Hrvatska), najveće svjetske poslovne organizacije, $u$ poslovima organizacije i promocije konferencija i edukacija iz područja međunarodne trgovine, bankarstva, društveno odgovornog poslovanja i arbitraže. Izvanredna je studentica preddiplomskog stručnog studija Marketinga i komunikacija Poslovnog veleučilišta Zagreb te je ujedno i dobitnica Dekanove nagrade za uspjeh. Njezino posebno područje interesa je organizacijska kultura.

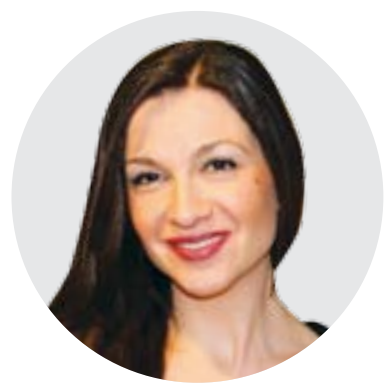

Vedrana Anđelić

Vedrana Anđelić zaposlena je u Hrvatskom zavodu za hitnu medicinu na radnom mjestu Viši stručni savjetnik za projekte, razvoj i zdravstvene tehnologije. Diplomirala je na Poslovnom veleučilištu Zagreb gdje je bila dobitnica više dekanovih nagrada za uspjeh te studentica generacije na preddiplomskom stručnom i specijalističkom diplomskom studiju marketinga i komunikacija. Poseban predmet interesa su joj novi mediji i turizam te je na tu temu provela nekoliko istraživanja i projekata. Aktivno prati trendove u komunikacijskoj tehnologiji i razvoju digitalnog tržišta. 